\title{
Comparative Analysis of the Physicochemical Parameters of Breast Milk, Starter Infant Formulas and Commercial Cow Milks in Serbia
}

\author{
Slavica Sunarić ${ }^{1}$, Tatjana Jovanović ${ }^{2}$, Ana Spasić ${ }^{3}$, Marko Denić ${ }^{3}$, Gordana Kocić ${ }^{4}$ \\ ${ }^{1}$ University of Niš, Faculty of Medicine, Department of Chemistry, Niš, Serbia \\ ${ }^{2}$ University of Niš, Faculty of Medicine, Department of Physics, Niš, Serbia \\ ${ }^{3}$ University of Niš, Faculty of Medicine, ${ }^{3} \mathrm{PhD}$ Student at Department of Pharmacy, Niš, Serbia \\ ${ }^{4}$ University of Niš, Faculty of Medicine, Department of Biochemistry, Niš, Serbia
}

\section{SUMMARY}

Data on the physical properties of cow milk and infant formulas are important since they indicate the differences in physicochemical and rheological characteristics and compatibility with natural breast milk. This fact is important not only for quality control but also for the use of these commercial products as infant diet supplements or as complete breast milk substitutes. This study was undertaken to determine refractive index, surface tension, $\mathrm{pH}$, electrical conductivity, viscosity and titratable acidity of the UHT cow milk, starter infant formulas and breast milk of Serbian mothers in order to compare commercial milk formulations with natural human milk. The paper also presents the measured data of some physical parameters of human milk about which there is little information in the literature. It has been also demonstrated how these parameters were changed by freezing and prolonged storage of breast milk.

In this study, 8 commercial cow milks, 6 starter infant formulas and 15 different samples of colostrum, transition and mature breast milk were included. The titratable acidity, $\mathrm{pH}$, electrical conductivity, refractive index, viscosity and surface tension were measured by using standardized techniques. It has been found that infant formulas available on the Serbian market differ in physicochemical parameters compared to breast milk. Regarding these parameters, none of the analyzed formulas fully corresponded to breast milk. It has been also shown that measurement of physical parameters is simple and inexpensive way to monitor the milk shelf-life which is important for human milk banks.

Key words: breast milk, infant formula, cow milk, physicochemical parameters 


\section{INTRODUCTION}

Breastfeeding is universal and the most appropriate form of nourishing the infants for the first 6 months postpartum (1). When breastfeeding is not possible, alternate sources of nutrients are required. Human milk is markedly different from cows' milk, both in terms of macronutrients and micronutrients (2, 3). Cow milk contains high concentrations of proteins and minerals which impedes digestion. In addition, cow milk lacks the iron, vitamin $C$ and some fats important for growing babies. For this reason, cow milk should not be used as the main drink before 12 months of age, although small volumes may be added to complementary foods (4).

Commercial infant formulas are commonly used either as baby diet supplements or as complete breast milk substitutes. The infant milk substitutes should be properly formulated so that nutritional requirements for optimal growth are met adequately (5). Most infant formulas are made with cow milk which has been altered to resemble human milk. The other types of formulas are soy-based and protein hydrolysate formulas. Milk substitute from plant sources does not contain all the nutrients in a healthy balance for infants (6).

The physicochemical characteristics such as refractive index, surface tension, $\mathrm{pH}$, conductivity, viscosity and titratable acidity are important parameters in studying quality and nutritional aspects of milk and milk products, because the physical and rheological properties strongly depend on chemical composition (7). The aim of this work was to investigate and compare the physicochemical parameters of commercial cow milks, breast milk and starter infant formulas in Serbia. Also, parameters for the fresh and frozen breast milk were compared and discussed.

\section{MATERIAL AND METHODS}

\section{Sample collection and preparation}

Cow milk samples were obtained from the market and included the most representative producers in Serbia. These milk samples were different in terms of milk fat and vitamin content. One of them was fortified with vitamins A and D. Also, one of the samples was obtained by organic production and one was without lactose. Samples of starter infant formulas (0-6 months) were purchased at a local pharmacy and were obtained from representative producers of infant food. Impamil ${ }$, Nan $A R \circledast$ and Humana $1 \circledR$ were formulas with prebiotics, while Hipp Organic ${ }^{\circledR}$ was organic infant milk. Nan $1 \circledR$ contained Bifidobacteriumlactis culture.

Human milk samples were collected at the Clinical Center Niš, Serbia, from the healthy volunteer women $(n=15)$ in different period of lactation covering colostrum, transition and mature milk. Additionally, the mature milk samples of every woman were categorized into 9 groups depending on the interval of the lactation during ten months.

All measurements were performed in undiluted samples of commercial and breast milk at room temperature. Commercial samples were analyzed immediately after opening. Breast milk samples obtained in the first 20 days postpartum were analyzed 2 hours after collection, while samples from the $30^{\text {th }}$ day to the $5^{\text {th }}$ month were analyzed after keeping for 3 months at $-20^{\circ} \mathrm{C}$. Infant formulas were prepared according to instructions given by producers: amount of $5 \mathrm{~g}$ of powder milk was weighted in the test tube, dissolved in $50 \mathrm{~mL}$ of deionized water and kept in a warm water bath for 10 $\min$.

\section{Apparatus}

Milk samples were analyzed for viscosity, refractive index, surface tension, conductivity, $\mathrm{pH}$ and titratable acidity. The electrical conductivity was measured by HANNA INSTRUMENTS EC 215 conductivity meter (Hanna Instruments USA, Smithfield, RI). For the measurement of $\mathrm{pH}$ CONSORT C830 multi-parameter analyser (Consort bvba, Turnhout, Belgium) was used. The refractive index was measured by using Abbe's refractometer and viscosity by using capillary flow type Ostwald Utube viscometer.

\section{Methods of measurements}

Titratable acidity (TA) was determined by using titrimetric method on this way: $9.0 \mathrm{~mL}$ of milk or dissolved infant formula sample is titrated with $0.1 \mathrm{~N}$ sodium hydroxide $(\mathrm{NaOH})$ in the presence of phenolphthalein as indicator. The obtained total acidity was expressed as \% of lactic acid and was calculated according to the equation: 
$\%$ lactic acid $=(\operatorname{Vg} \times 100 \times 0.009) / \mathrm{Vm}(1)$

where $\mathrm{Vg}$ is the added volume of $\mathrm{NaOH}$ solution $(\mathrm{mL}) ; \mathrm{Vm}$ is the milk volume used for titration $(\mathrm{mL})$ and 0.009 is equivalent of lactic acid normality (8).

Viscosity was determined by the flow time of the fluid and by gravity through the Ostwald's viscometer at $25^{\circ} \mathrm{C}$. The time in seconds was converted into dynamic viscosity by using the diameter of the capillary and the formula:

$$
\eta_{x}=\eta_{0}^{\tau} \frac{\rho_{x} \cdot t_{x}}{\rho_{0} \cdot t_{0}}(2)
$$

where, Qx and Qo are densities of examined samples and water and $\eta_{0}^{\tau}$ is the coefficient of viscosity of water at $25^{\circ} \mathrm{C}$.

The coefficient of surface tension was determined by using stalagmometer by the drop number method. The mean values of the number of drops for the sample and water ( $n_{x}$ and $\left.n_{0}\right)$ were used to calculate the surface tension of the sample fluid according to equation:

$$
T_{X}=T_{0} \frac{\sigma_{x} n_{0}}{\sigma_{0} n_{x}}(3)
$$

where, $T_{0}$ is the surface tension coefficient of distilled water, $\sigma_{x}$ and $\sigma_{0}$ are the specific weights of the sample and distilled water.

\section{RESULTS AND DISCUSSION}

The physicochemical parameters of the commercial cow milks, infant formulas and human milk are given in Tables 1, 2 and 3, respectively. The measurements were repeated at least in triplicate and the results are presented as mean value \pm standard deviation.

\section{Electrical conductivity}

The conductivity test was primarily standardized for the rapid quality control of cow's milk and it is important to detect abnormal milk (9). The electrical conductivity of milk is mainly due to the presence of various electrolytes (soluble salt fraction), nonelectrolytes and fat content. The main conductors in milk and milk products are sodium, potassium and chlorides ions. Lactic acid and its salts are also important conductors. On the other hand, the non-electrolytes (lactose, urea, proteins, peptides, sugars and fats) do not directly contribute to the electrical conductivity, but they affect it through their influence on the viscosity and the ions migration. Thus, in a heterogeneous system such as milk, fats obstruct the ions migration and decrease the conductivity (9-11).

The conductivity range of all the examined commercial milk samples was from $3.84 \mathrm{mS} / \mathrm{cm}$ to 4.06 $\mathrm{mS} / \mathrm{cm}$, as shown in Table 1 . The organic produced commercial cow milk Bello organic ${ }^{\circledR}$ with $2.8 \%$ of milk fat showed the lowest value of the conductivity. The electrical conductivity of the fresh breast milk was in the range of 1.46-1.89 mS/cmand decreased with the period of lactation. Frozen mature breast milks had slightly lower values of conductivity than fresh mature milk. The values of the conductivity of infant formulas were lower than those of commercial cow milk. Among the infant formula samples, the lowest conductivity was found for Humana $1{ }^{\circledR}$ and the highest was for the Impamil ${ }^{\circledR}$. These conductivities are more adjusted to those for breast milk, especially to colostrums, than conductivities of commercial cow milks. Only Humana $1{ }^{\circledR}$ had electrical conductivity similar to those of transition and mature breast milk.

\section{Refractive index (RI)}

Optical properties of milk determine the appearance of milk and milk products. The refraction of light by solution depends on the individual molecular species present and their concentrations (9). The refractive index of milk is the sum of the refractive index of the solvent and solutes, therefore, this parameter is useful for estimation of total solids in milk or the content of water which was added to milk. The refractive index of milk is difficult to estimate due to light scattering by casein micelles and fat globules; however, by using Abbe's refractometer it is possible to make satisfactory measurements (12).

The refractive index of the fresh breast milk samples were found to be 1.3494 to 1.3510 , that is lower than RI of commercial milks and most of the infant formulas. On the other hand, most of the infant formulas had similar RI values to commercial cow milks, although slight variations were found for this parameter in all of examined samples. Thus, Nan AR® had RI similar to transitional milk, while Impamil ${ }^{\circledR}$ had RI close to colostrum. 


\section{Titratable acidity (TA) and $p H$}

The natural acidity is an important characteristic of fresh milk and is mainly due to the presence of proteins, phosphates, carbon dioxide and citrates. Another important characteristic of milk is its buffering capacity. The principal buffering compounds in milk are its salts (soluble calcium phosphate, citrate and bicarbonate) and acidic and basic amino acid side-chains on proteins (particularly the casein) (9). Titratable acidity (TA) is a parameter suitable for expressing the natural acidity and buffering capacity, because it is a measure of the total acid content (dissociated and undissociated). On the other hand, $\mathrm{pH}$ is a measure of the free $\mathrm{H}^{+}$ions concentration obtained from dissociation of acids present in milk. Therefore, there is no direct relationship between $\mathrm{pH}$ and TA. It is possible to obtain high $\mathrm{pH}$ and high TA values, which suggests high concentrations of proteins and other buffering compounds.

Titratable acidity of our fresh human milk samples varies from $0.02 \%$ to $0.07 \%$ of lactic acid. Higher TA value for colostrum can be explained due to its high protein content. In the infant formula samples, the average TA was $0.0608 \pm 0.014 \%$ of lactic acid, which is more similar to that of colostrum and transition milk than that of mature breast milk. Based on the standard deviation, it can be concluded that the differences in titratable acidity are relatively high among infant formulas. The values of TA for commercial cow milk (average $0.166 \pm 0.007 \%$ of lactic acid) were significantly higher than those for infant formulas or breast milk, because cow milk has higher protein content $(3.4 \%$ versus $1.0 \%$ for human milk) and particularly high casein content (9).

Commercial milks and some of the infant formulas have $\mathrm{pH}$ values in the range of 6.5-6.65. Only two of the investigated infant formulas had $\mathrm{pH}$ round 6.90 that is very similar to $\mathrm{pH}$ of the fresh human colostrums. All of the infant formulas had $\mathrm{pH}$ lower than fresh transitional and mature breast milk. This result suggests that commercial products for infant feeding from our market are not fully adjusted to the composition of the breast milk.

The examined mature breast milk samples which were frozen for three months at $-20^{\circ} \mathrm{C}$ had significantly lower values of $\mathrm{pH}$ and higher values of TA than fresh breast milk (Table 3). This is due to the lipolysis as well as bacterial growth (7). During cold or frozen storage of human milk, lipoprotein lipase causes hydrolysis of milk triglycerides which yields to release of the free fatty acids (13). Also, the conversion of lactose to lactic acid may occur by the activity of bacteria even at $-20^{\circ} \mathrm{C}$ (12). The elevated TA values of frozen breast milk are not acceptable and those milk samples are unsuitable for infant nutrition.

\section{Viscosity}

Viscosity is a parameter that defines flow properties of milk or milk products. Milk and milk products are fluids with Newtonian rheological properties, meaning that they exhibit a direct proportionality between shearing stress and rate of shear. The viscosity of milk and milk products is mainly influenced by composition, concentration of components, $\mathrm{pH}$, temperature and thermal history. Casein and fats are the principal contributors to the viscosity of milk (7). Viscosity is an important rheological property of breast milk because it determines the ease of swallowing by infants. There are few recent data about the viscosity of human milk $(15,16)$.

The examined fresh mature breast milk samples had the lowest viscosity, followed by the infant formulas and commercial cow milks. Frozen mature breast milks had lower viscosity than fresh mature milk (average $\left.1.36 \pm 0.04 \mathrm{~Pa} \cdot \mathrm{s} 10^{-3}\right)$, which is probably related with reactions explained above. Among the products for infant feeding, the lowest value for viscosity was found for Nan $A R \AA$ and the highest value was for Humana $1 \AA$. The samples of Humana1 ${ }^{\circledR}$ were very viscous, so the measurement could not be done with satisfactory accuracy and precision. Further, Aptamil ${ }^{\circledR}$ and Hipp Organic ${ }^{\circledR}$ had viscosity similar to colostrum, while viscosity of Nan AR® was mostly like those for transition and mature breast milk. In the liquid-packed commercial cow milk samples, the UHT milk fortified with the vitamins $A$ and $D$, Imlek $A+D_{3} \circledast$, had the lowest viscosity and the Zdravo ${ }^{\circledR}$ with $3.5 \%$ of milk fat had the highest viscosity.

\section{Surface tension}

The surface tension is defined as the work required to increase the surface area of a solution. The main surfactants in milk are proteins, phospholipids, mono- and diglycerides and salts of free fatty acids (7). A higher content of non-polar molecules results in lower values of the surface tension of the liquid. Thus, the increase of fat content results in surface tension decrease.

In the examined fresh breast milk samples, the average value of surface tension was $(46.99 \pm 1.21) \times 10^{-3}$ 
$\mathrm{N} / \mathrm{m}$, while for the frozen samples the surface tension was decreased with the period of lactation; the values ranged from $44.91 \times 10^{-3} \mathrm{~N} / \mathrm{m}$ to $34.62 \times 10^{-3} \mathrm{~N} / \mathrm{m}$. The lower surface tension of frozen milks is expected, because fatty acids and their salts, formed as a result of lipolysis, are surface active and reduce surface tension (17). Although the method of surface tension measurement is not applied routinely for the lipolysis assessment, it can be used for the estimation of the milk freshness as well as the excess of lipase. The excess of lipase in breast milk is noticed in some women and leads to a change in taste and smell of milk (18).
The average surface tension of commercial formulas for infant feeding was found to be $(66.3 \pm 3.2) \times$ $10^{-3} \mathrm{~N} / \mathrm{m}$, that is significantly different from the breast milk in all of the lactation periods. This result indicates the differences in chemical composition and concentrations of bioactive compounds in breast milk and infant formulas. In the various liquid-packed commercial cow milks these values ranged 58.54-61.14 $\times$ $10^{-3} \mathrm{~N} / \mathrm{m}$ with a tendency of decreasing with the increase of the fat content. Special commercial formulations, milk without lactose and product obtained from organic milk, had the highest values of surface tension.

Table 1. Physicochemical parameters of the commercial cow milks ( $\overline{\mathrm{X}} \pm \mathrm{SD})$

\begin{tabular}{|c|c|c|c|c|c|c|}
\hline $\begin{array}{l}\text { Commercial } \\
\text { cow milk } \\
\text { (fat content) }\end{array}$ & $\begin{array}{c}\text { Electrical } \\
\text { conductivity } \\
(\mathrm{mS} / \mathrm{cm})\end{array}$ & $\begin{array}{l}\text { Refractive } \\
\text { index }\end{array}$ & $\begin{array}{l}\text { Dynamic } \\
\text { viscosity } \\
\left(\mathbf{P a} \cdot \mathrm{s} 10^{-3}\right)\end{array}$ & $\begin{array}{c}\text { Surface } \\
\text { tension } \\
\left(10^{-3} \mathrm{~N} / \mathrm{m}\right)\end{array}$ & $\begin{array}{c}\text { Titratable } \\
\text { acidity } \\
\text { (\% of lactic acid) }\end{array}$ & $\mathrm{pH}$ \\
\hline Bello organic $(2.8 \%)$ & $3.84 \pm 0.10$ & $1.3554 \pm 0.0003$ & $2.273 \pm 0.015$ & $61.1420 \pm 0.88$ & $0.1525 \pm 0.0009$ & $6.64 \pm 0.02$ \\
\hline Imlek ${ }^{\circledR}(3.2 \%)$ & $4.06 \pm 0.08$ & $1.3574 \pm 0.0004$ & $1.975 \pm 0.010$ & $59.5033 \pm 0.90$ & $0.1675 \pm 0.0011$ & $6.56 \pm 0.03$ \\
\hline Imlek $A+D_{3} 囚(3.2 \%)$ & $4.01 \pm 0.10$ & $1.3563 \pm 0.0002$ & $1.7806 \pm 0.008$ & $58.9772 \pm 0.95$ & $0.1725 \pm 0.0013$ & $6.51 \pm 0.02$ \\
\hline Meggle® $(2.8 \%)$ & $3.95 \pm 0.08$ & $1.3514 \pm 0.0005$ & $1.883 \pm 0.011$ & $60.1348 \pm 1.10$ & $0.170 \pm 0.0038$ & $6.53 \pm 0.03$ \\
\hline Meggle Vita ${ }^{\circledR}(2.8 \%)$ & $3.97 \pm 0.11$ & $1.3564 \pm 0.0009$ & $1.8953 \pm 0.013$ & $60.5858 \pm 1.67$ & $0.1675 \pm 0.0045$ & $6.52 \pm 0.02$ \\
\hline Imlek $®(2.8 \%)$ & $4.04 \pm 0.08$ & $1.3514 \pm 0.0009$ & $2.0065 \pm 0.020$ & $58.5412 \pm 1.58$ & $0.170 \pm 0.0015$ & $6.56 \pm 0.02$ \\
\hline Zdravo® $(3.5 \%)$ & $3.96 \pm 0.09$ & $1.3554 \pm 0.0008$ & $2.5303 \pm 0.025$ & $58.8719 \pm 1.55$ & $0.1575 \pm 0.0025$ & $6.63 \pm 0.03$ \\
\hline Imlek without & $3.99 \pm 0.08$ & $1.3535 \pm 0.0009$ & $1.9094 \pm 0.013$ & $61.142 \pm 1.10$ & $0.170 \pm 0.0028$ & $6.51 \pm 0.01$ \\
\hline
\end{tabular}

Table 2. Physicochemical parameters of the infant formulas $(\overline{\mathrm{X}} \pm \mathrm{SD})$

\begin{tabular}{|c|c|c|c|c|c|c|}
\hline Infant formula & $\begin{array}{c}\text { Electrical } \\
\text { conductivity } \\
(\mathrm{mS} / \mathrm{cm})\end{array}$ & $\begin{array}{l}\text { Refractive } \\
\text { index }\end{array}$ & $\begin{array}{l}\text { Dynamic } \\
\text { viscosity } \\
\left(\mathrm{Pa} \cdot \mathrm{s} \mathrm{10} \mathbf{1 0}^{-3}\right)\end{array}$ & $\begin{array}{l}\text { Surface tension } \\
\qquad\left(10^{-3} \mathrm{~N} / \mathrm{m}\right)\end{array}$ & $\begin{array}{c}\text { Titratable } \\
\text { acidity } \\
\text { (\% lactic acid) }\end{array}$ & $\mathrm{pH}$ \\
\hline Nan AR® & $1.80 \pm 0.02$ & $1.3494 \pm 0.0004$ & $1.6636 \pm 0.075$ & $65.5188 \pm 0.80$ & $0.055 \pm 0.005$ & $6.52 \pm 0.03$ \\
\hline Aptamil@ & $1.88 \pm 0.03$ & $1.3524 \pm 0.0005$ & $2.6505 \pm 0.102$ & $68.6717 \pm 0.90$ & $0.0725 \pm 0.004$ & $6.89 \pm 0.02$ \\
\hline Humana 1® & $1.55 \pm 0.02$ & $1.3534 \pm 0.0005$ & $>4$ & $60.9585 \pm 0.65$ & $0.0375 \pm 0.004$ & $6.90 \pm 0.02$ \\
\hline Nan 1® & $1.83 \pm 0.04$ & $1.3565 \pm 0.0007$ & $1.9044 \pm 0.086$ & $69.7753 \pm 0.85$ & $0.0575 \pm 0.0035$ & $6.54 \pm 0.03$ \\
\hline Impamil ${ }^{\circledR}$ & $2.28 \pm 0.08$ & $1.3515 \pm 0.0006$ & $1.8792 \pm 0.100$ & $67.9234 \pm 0.95$ & $0.075 \pm 0.0030$ & $6.58 \pm 0.01$ \\
\hline Hipp Organic ${ }^{\circledR}$ & $1.94 \pm 0.05$ & $1.3574 \pm 0.0005$ & $2.2287 \pm 0.065$ & $64.9210 \pm 0.75$ & $0.0675 \pm 0.002$ & $6.72 \pm 0.01$ \\
\hline
\end{tabular}


Table 3. Physicochemical parameters of the fresh human milk (*) and frozen samples in different periods of lactation $(\overline{\mathrm{X}} \pm \mathrm{SD})$

\begin{tabular}{|c|c|c|c|c|c|c|}
\hline $\begin{array}{l}\text { Period of } \\
\text { lactation }\end{array}$ & $\begin{array}{c}\text { Electrical } \\
\text { conductivity } \\
(\mathrm{mS} / \mathrm{cm})\end{array}$ & $\begin{array}{l}\text { Refractive } \\
\text { index }\end{array}$ & $\begin{array}{l}\text { Dynamic } \\
\text { viscosity } \\
\left(\text { Pa.s } 10^{-3}\right)\end{array}$ & $\begin{array}{c}\text { Surface } \\
\text { tension } \\
\left(10^{-3} \mathrm{~N} / \mathrm{m}\right)\end{array}$ & $\begin{array}{c}\text { Titratable } \\
\text { acidity } \\
\text { (\% lactic acid) }\end{array}$ & $\mathrm{pH}$ \\
\hline $4^{\text {th }}$ day $^{*}$ & $1.89 \pm 0.02$ & $1.3510 \pm 0.0003$ & $2.3988 \pm 0.010$ & $47.7314 \pm 1.50$ & $0.070 \pm 0.004$ & $6.99 \pm 0.03$ \\
\hline $10^{\text {th }}$ day $^{*}$ & $1.55 \pm 0.025$ & $1.3494 \pm 0.0005$ & $1.4442 \pm 0.010$ & $47.6617 \pm 1.10$ & $0.051 \pm 0.005$ & $7.07 \pm 0.03$ \\
\hline $20^{\text {th }}$ day $^{*}$ & $1.46 \pm 0.02$ & $1.3504 \pm 0.0003$ & $1.4583 \pm 0.007$ & $45.5982 \pm 1.35$ & $0.023 \pm 0.008$ & $7.24 \pm 0.05$ \\
\hline $30^{\text {th }}$ day & $1.36 \pm 0.03$ & $1.3485 \pm 0.0003$ & $1.3860 \pm 0.0065$ & $44.9082 \pm 1.10$ & $0.075 \pm 0.004$ & $6.36 \pm 0.01$ \\
\hline $6^{\text {th }}$ week & $1.30 \pm 0.02$ & $1.3489 \pm 0.0002$ & $1.3522 \pm 0.007$ & $40.8104 \pm 0.95$ & $0.090 \pm 0.005$ & $6.36 \pm 0.02$ \\
\hline $9^{\text {th }}$ week & $1.40 \pm 0.02$ & $1.3488 \pm 0.0004$ & $1.4008 \pm 0.009$ & $37.1425 \pm 0.70$ & $0.085 \pm 0.005$ & $6.26 \pm 0.01$ \\
\hline $10^{\text {th }}$ week & $1.33 \pm 0.03$ & $1.3486 \pm 0.0003$ & $1.3463 \pm 0.007$ & $42.5108 \pm 0.95$ & $0.105 \pm 0.007$ & $6.26 \pm 0.04$ \\
\hline $12^{\text {th }}$ week & $1.42 \pm 0.025$ & $1.3482 \pm 0.0005$ & $1.2815 \pm 0.006$ & $35.9563 \pm 0.80$ & $0.100 \pm 0.003$ & $6.34 \pm 0.03$ \\
\hline $14^{\text {th }}$ week & $1.43 \pm 0.015$ & $1.3486 \pm 0.0003$ & $1.4019 \pm 0.010$ & $36.9743 \pm 0.85$ & $0.108 \pm 0.005$ & $6.20 \pm 0.05$ \\
\hline $4^{\text {th }}$ month & $1.38 \pm 0.04$ & $1.3493 \pm 0.0002$ & $1.3857 \pm 0.007$ & $37.0162 \pm 0.95$ & $0.125 \pm 0.004$ & $6.13 \pm 0.04$ \\
\hline $5^{\text {th }}$ month & $1.36 \pm 0.04$ & $1.3494 \pm 0.0002$ & $1.3158 \pm 0.006$ & $34.6217 \pm 0.75$ & $0.098 \pm 0.005$ & $6.25 \pm 0.04$ \\
\hline
\end{tabular}

\section{CONCLUSIONS}

The physicochemical parameters of milk and milk formulas are highly complex, because they are composed of a mixture of fat globules and proteins in an aqueous solution of vitamins, lactose, minerals and a large number of other minor constituents. The determination of physicochemical and rheological parameters could be useful for the estimation of commercial milks, infant formulas and breast milk

Republic of Serbia. quality. Also, physicochemical parameters of frozen breast milk could be important for milk shelf-life monitoring in human milk banks.

\section{Acknowledgements}

This research was supported by grant TR 31060 from the Ministry of Education and Science of the 


\section{References}

1. World Health Organization. Infant and young child feeding: Model chapter for textbooks for medical students and allied heath professionals. Washington, DC: Author, 2009.

2. Kocic GM, Jevtovic-Stoimenov T, Sokolovic D et al. Milk consumption and chronic disease riskthe strategy or challenge to avoid and eliminate "unwanted" compounds and contaminants. J AgrSci 2015; 7(5): 154-62.

http://dx.doi.org/10.5539/jas.v7n5p154

3. Kocic G, BjelakovicLj, Cvetkovic T et al. Enzyme activity of human milk during the first month of lactation. Acta Med Median 2010; 49(2): 20-4.

4. Agostoni C, Braegger C, Decsi T et al. Breastfeeding: a commentary by the ESPGHAN Committee on Nutrition. J Pediatr Gastroenterol Nutr 2009; 49:112-25.

http://dx.doi.org/10.1097/MPG.0b013e31819f1e05

5. Aggett PJ, Agostini C, Goulet $\mathrm{O}$ et al. The nutritional and safety assessment of breast milk substitutes and other dietary products for infants: a commentary by the ESPGHAN Committee on Nutrition. J Pediatr Gastroenterol Nutr 2001; 32: 256-8.

http://dx.doi.org/10.1097/00005176-20010300000004

6. www.mayoclinic.org

7. Fox PF, Uniacke-Lowe T, Mc Sweeney PLH, O'Mahony JA. Physical properties of milk. In: Dairy Chemistry and Biochemistry, 2nd edition, Springer International Publishing, Switzerland, 2015: 321-342.

http://dx.doi.org/10.1007/978-3-319-14892-2_8

8. AOAC. Official Methods of Analysis of AOAC, 15th ed. Association of Official Analytical Chemists, Arlington, Virginia US, 1990.

9. Fox PF, Mc Sweeney PLH. Dairy Chemistry and Biochemistry, 1st ed. Blackie Academic\&Professional, London, 1998.
10. Kermack WO, Miller RA. The electrical conductivity and chloride content of women's milk; part I: methods and practical application. Arch Dis Child 1951; 26 (127): 265-9. http://dx.doi.org/10.1136/adc.26.127.265

11. Mucchetti G, Gatti M, Neviani E. Electrical conductivity changes in milk caused by acidification: determining factors. J Dairy Sci 1994; 77: 940-4.

http://dx.doi.org/10.3168/jds.S0022-0302(94)77029-6

12. Marth EH. Fundamentals of Dairy Chemistry, 3rd ed. Aspen Publication, Maryland,1999.

13. Berkow SE, Freed LM, Hamosh M et al. Lipase and lipids in human milk: effect of freezethawing and storage. Pediatr Res 1984; 18(12): 1257-62. http://dx.doi.org/10.1203/00006450-19841200000006

14. Bortolozo EFQ Pietroski G, Baggio $R$ et al. Padraomicrobiologico e sanitario do leite humane processadoem banco de leite. HigieneAlimentar 2004; 12: 85-8.

15. Corvaglia L, Ferlini M, Rotatori R et al. Starch thickening of human milk is ineffective in reducing the gastroesophageal reflux in preterm infants: A crossover study using intraluminal impedance. J Pediatr 2006; 148: 265-8. http://dx.doi.org/10.1016/j.jpeds.2005.09.034

16. Almeida MBM, Almeida JAG, Moreira ME et al. Adequacy of human milk viscosity to respond to infants with dysphagia: experimental study. J Appl Oral Sci 2011; 19(6): 554-9. http://dx.doi.org/10.1590/S1678-77572011000600003

17. Jensen RG, ed. Handbook of milk composition. Academic Press, San Diego California, 1995: 81115.

18. Lawrence RA, Lawrence RM. Breastfeeding: a guide for the medical profession, 7th ed. Elsevier Mosby, Missouri, 2011. 


\title{
Uporedna analiza fizičko-hemijskih parametara humanog mleka, početnih infant formula I komercijalnog kravljeg mleka na srpskom tržištu
}

\author{
Slavica Sunarić1, Tatjana Jovanović2, Ana Spasić3, Marko Denić3 ${ }^{3}$ Gordana Kocić ${ }^{4}$ \\ ${ }^{1}$ Univerzitet $u$ Nišu, Medicinski fakultet, Katedra za hemiju, Niš, Srbija \\ ${ }_{2}^{2}$ Univerzitet $u$ Nišu, Medicinski fakultet, Katedra za fiziku, Niš, Srbija \\ ${ }^{3}$ Univerzitet u Nišu, Medicinski fakultet, Student doktorskih studija na Katedri za farmaciju, Niš, Srbija \\ ${ }^{4}$ Univerzitet u Nišu, Medicinski fakultet Katedra za biohemiju, Niš, Srbija
}

\section{SAŽETAK}

Fizički parametri komercijalnog mleka i infant formula su značajan pokazatelj fizičkih i reoloških karakteristika, što je važno kako za procenu kvaliteta tako i za mogućnost primene ovih proizvoda kao dopune $u$ ishrani ili potpune zamene za majčino mleko. Fizički parametri mleka $i$ mlečnih proizvoda $u$ velikoj meri zavise od njihovog hemijskog sastava, tj. od odnosa makro- i mikronutrijenata. $U$ ovom radu mereni su indeks prelamanja, površinski napon, $\mathrm{pH}$, električna provodljivost, viskozitet i titrabilna kiselost UHT sterilizovanog kravljeg mleka, početnih infant formula i humanog mleka. Cilj rada bio je upoređivanje komercijanih mlečnih proizvoda sa prirodnim mlekom dojilja iz našeg regiona. $U$ radu su, takođe, date eksperimentalno dobijene vrednosti fizičkih parametara humanog mleka, za koje, inače, ima malo podataka u literaturi. Pokazano je i kako se ovi parametri menjaju usled zamrzavanja i dužeg čuvanja humanog mleka.

U studiji je korišćeno 8 vrsta komercijalnog kravljeg mleka (UHT) sa domaćeg tržišta, 6 početnih infant formula stranih proizvođača, koje su dostupne na našem tržištu i uzorci kolostruma, prelaznog i starog humanog mleka uzeti od 15 žena. Titrabilna kiselost, pH, električna provodljivost, indeks prelamanja, viskoznost i površinski napon mereni su standardnim fizičko-hemijskim tehnikama. Nađeno je da postoji razlika u fizičko-hemijskim parametrima humanog mleka i infant formula koje su dostupne na našem tržištu i da nijedna od ispitanih formula nije po ovim parametrima u potpunosti odgovarala humanom mleku. Ispitivane početne mlečne formule su se i međusobno dosta razlikovale po izmerenim vrednostima električne provodljivosti, indeksa prelamanja, viskoznosti, površinskog napona, titrabilne kiselosti i $\mathrm{pH}$, na osnovu čega se zaključuje da postoji neujednačenost u pogledu kvalitativnog i kvantitativnog sastava ovih proizvoda. Takođe, pokazano je da je merenje fizičkih parametara humanog mleka jednostavan i jeftin način da se proverava kvalitet i prati rok upotrebe zamrznutih uzoraka, što može biti vrlo značajno za čuvanje humanog mleka u bankama mleka.

Ključne reči: humano mleko, infant formula, kravlje mleko, fizičko-hemijski parametri 